EFFCENT

\title{
Community Participation Level in Development of Keseneng Tourism Village
}

\author{
Adnan Abdul Safii ${ }^{1}$, Amin Pujiati ${ }^{2 \bowtie}$ \\ Jurusan Ekonomi Pembangunan, Fakultas Ekonomi, Universitas Negeri Semarang
}

Permalink/DOI: https://doi.org/10.15294/efficient.v2i2.30795

Received: December 2018 ; Accepted: March 2019 ; Published: Juny 2019

\begin{abstract}
This research aims to identify the level of community participation in the development of Keseneng Tourism Village, to know the inhibiting factors in the development of tourism villages, and to identify efforts to overcome obstacles to increase the participation of the Keseneng Village community. The design in this study is a case study research with a type of qualitative descriptive research. The data used are primary and secondary data. Data collection techniques used are observation, interviews and documentation. The data validity technique uses triangulation techniques. Trianggulation technique means using different data collection techniques to get data from the same source. The results showed that the level of community participation in the development of the Keseneng Tourism Village using the Arnstein ladder was in the stage of Placatation. Participation in the threatening stage means that the communication made by the community and the government has been done well. The community also has the opportunity to place its representatives in the development of Keseneng Tourism Village activities. The inhibiting factors in the development of Keseneng Tourism Village are lack of funding, quality of Human Resources, knowledge and insights of the community regarding tourism villages, and incomplete facilities and infrastructure. Efforts are being made to overcome obstacles by disseminating tourism, providing skills training, fostering tourism villages, participating in marketing and publishing Keseneng Tourism Village, as well as comparative studies to other tourist villages. .
\end{abstract}

Keywords: Community Participation, Development, Inhibiting Factors, Tourism Villages

\begin{abstract}
Abstrak
Penelitian ini bertujuan untuk mengidentifikasi tingkat partisipasi masyarakat dalam pengembangan Desa Wisata Keseneng, mengetahui faktor penghambat dalam pengembangan desa wisata, serta mengetahui upaya dalam mengatasi hambatan untuk meningkatkan partisipasi masyarakat Desa Keseneng. Desain dalam penelitian ini adalah penelitian studi kasus dengan jenis penelitian deskriptif kualitatif. Data yang digunakan adalah data primer dan sekunder. Teknik pengumpulan data yang digunakan adalah observasi, wawancara serta dokumentasi. Teknik keabsahan data menggunakan trianggulasi teknik. Hasil penelitian menunjukkan bahwa tingkat partisipasi masyarakat pengembangan Desa Wisata Keseneng menggunakan tangga Arnstein berada pada tahap Penentraman (Placatation). Partisipasi tahap Penetraman berarti bahwa komunikasi yang dilakukan masyarakat dan pemerintah telah dilakukan dengan baik. Masyarakat juga memiliki kesempatan untuk menempatkan perwakilannya dalam kegiatan pengembangan Desa Wisata Keseneng. Faktor penghambat dalam pengembangan Desa Wisata Keseneng yaitu kurangnya pendanaan, kualitas Sumber Daya Manusia, pengetahuan dan wawasan masyarakat mengenai desa wisata, serta sarana dan prasarana belum lengkap. Upaya yang dilakukan masyarakat dan pemerintah untuk mengatasi hambatan dengan melakukan sosialisasi kepariwisataan, memberikan pelatihan keterampilan, pembinaan desa wisata, ikut memasarkan dan mempublikasikan Desa Wisata Keseneng, serta studi banding ke desa wisata lain.
\end{abstract}

Kata Kunci: Partisipasi Komunitas, Pembangunana, Faktor Penghambat, Desa Wisata

How to Cite: Safii, A., \& Pujiati, A. (2019). Community Participation Level in Development of Keseneng Tourism Village. EFFICIENT Indonesian Journal of Development Economics, 2(2), 376-386. https://doi.org/10.15294/efficient.v2i2.30795

(c) 2019 Semarang State University. All rights reserved

\footnotetext{
Alamat Korespondensi :

Alamat: Gedung L2 Lantai 2 FE Unnes

Kampus Sekaran, Gunungpati, Semarang, 50229

E-mail : adnanespero@gmail.com
}

ISSN 2655-6197 


\section{INTRODUCTION}

Tourism is one of the leading sectors for the Indonesian economy. The tourism sector is also one of the strategic sectors in developing national and regional economies, in addition to the tax sector. This sector has become part of the development of the global economy whose growth is very fast (Rahayu, 2006).

Based on Government Regulation of the Republic of Indonesia No. 50 of 2011 in the RIPPARNAS (National Tourism Development Master Plan) in 2010-2025, Central Java Province, one of The National Tourism Strategic Areas (KSPN). The tourism sector in Central Java province is considered a potential sector in contributing to regional income. Tourism development needs to be done in a comprehensive and integrated manner to be able to attract visitors both locally and from outside the region (Taufiqurrohman, 2014). The tourism sector in the province of Central Java is able to contribute substantial regional income to the income of the province of
Central Java. The following is a contribution from the tourism sector of the province of Central Java.

Table 1. Income Sector Tourism Central Java Province Year 2013 - 2017

Year Income ( Rp ) Percentage Growth

\begin{tabular}{llc}
\hline 2013 & $214,513,465,633$ & - \\
2014 & $232,510,898,616$ & $8 \%$ \\
2015 & $238,373,330,846$ & $3 \%$ \\
2016 & $262,984,817,326$ & $10 \%$ \\
2017 & $289,496,115,420$ & $11 \%$ \\
\hline
\end{tabular}

Source : Tourism Office Central Java Province, 2017.

From table 1 it can be seen that the income of the tourism sector in Central Java province each year has a tendency to increase. Increased income in the tourism sector is caused by the increase in tourist attraction in Central Java, resulting in increasing tourists visiting Central Java province.

Table 2. Number of Foreign and Domestic Tourists in Central Java Province, 2013 - 2017

\begin{tabular}{cccc}
\hline Year & Foreign Tourists (People) & Domestic Tourists (People) & Total \\
\hline 2013 & 388.143 & 29.430 .609 & 29.818 .752 \\
2014 & 419.584 & 29.852 .095 & 30.271 .679 \\
2015 & 375.166 & 31.432 .080 & 31.807 .246 \\
2016 & 578.924 & 36.899 .776 & 37.478 .700 \\
2017 & 781.107 & 40.118 .470 & 40.889 .577 \\
\hline
\end{tabular}

Sources: Tourism Office Central Java Province, 2017.

The Joglosemar area (Yogyakarta, Solo and Semarang) is a golden triangle area which is the center of economic growth. As a buffer for the provincial capital of Central Java, Semarang Regency is a city that has the potential to be developed into a tourist destination. In accordance with the Regional
Regulation of Central Java Province No. 10 of 2012 concerning the Central Java Provincial Development Plan for Tourism (RIPPAR PROV) in 2012-2027 article 10 states that Semarang became one of the Central Java Province Tourism Destinations (DPP). Semarang Regency is also a tourism 
destination for urbanites. The strategic position of Semarang Regency as a buffer for the capital of Central Java Province has hill and mountainous natural conditions that have cool temperatures (Semarang Regency RPJMD 2016-2021).

Table 3. Number of Tourist Visits in the Attractiveness of Tourism Spot (DTW) Semarang Regency, Year 2013- 2017

\begin{tabular}{lccc}
\hline Year & $\begin{array}{l}\text { Domestic } \\
\text { Tourists }\end{array}$ & $\begin{array}{l}\text { Foreign } \\
\text { Tourists }\end{array}$ & Total \\
\hline 2013 & $1,363,769$ & 3.683 & $\mathbf{1 , 3 6 7 , 4 5 2}$ \\
2014 & $1,523,824$ & 2,725 & $1,526,549$ \\
2015 & $2,111,020$ & 3,381 & $\mathbf{2 , 1 1 4 , 4 0 1}$ \\
2016 & $\mathbf{2 , 2 2 8 , 5 0 0}$ & 3.209 & $\mathbf{2 , 2 3 1 , 7 0 9}$ \\
2017 & $\mathbf{2 , 8 1 2 , 5 5 4}$ & 9,867 & $\mathbf{2 , 8 2 2 , 4 2 1}$ \\
\hline
\end{tabular}

Source: Tourism Office Central Java

Province, 2017.

Based on the Semarang Regency Regent Decree Number: 556/0424/2015 concerning the Determination of Tourism Villages, Semarang Regency has formed 35 tourist villages spread over 19 sub-districts. Every tourist village has its own advantages and characteristics. One village that has the advantage of being a tourist destination is Keseneng Village.

Keseneng Village is a village in Sumowono Subdistrict, Semarang Regency, about $35 \mathrm{~km}$ from Semarang City. Keseneng Village is a tourist village established by the Semarang Regency Government as a mainstay tourist village on June 18,2015 , and is one of the priorities of the Regional Tourism Destinations (DPP) of Gedong Songo Keseneng in the development of Semarang Regency tourism destinations. Keseneng Village is also one of the alternative tourist destinations in Semarang Regency (Nurseptiani \& Mustam, 2015).

In the management of tourist villages, community participation is really needed because the tourism sector is very much in need of participation from the community. In every tourism activity it is very important for the presence of the community. According to (Wahidin, 2017) mentioning that the community is currently being sued not only as an object of tourism, but as a subject of tourism so that the community has responsibility in developing tourism objects in their area and getting a real economic impact in the form of increasing community income.

Local communities, especially indigenous people who live in tourist areas have become one of the key actors in managing tourist destinations because they provide the majority of tourist attractions. Actually, the community has the ability to contribute to the management of tourist destinations optimally, so they are given the opportunity to plan, manage and utilize these tourist destinations. With the opportunity for the community to participate in the management of tourism destinations, the community will feel involved and feel that they are taking care.

In truth, in the process of developing and managing this tourist village, it requires community participation so that people can feel that they have a tourist village. If the community is involved, the community can channel their aspirations towards the development of this tourist village. In the concept of tourism villages that should be the subject of development is the community. It is the community who plans, manages and later 
will be able to benefit from the existence of this tourist village in his village. According to opinion (Mak, Cheung, \& Hui, 2017) which states that community participation is carried out in order to obtain economic benefits, benefit the tourism sector, and for sustainable development.

Looking at these conditions, the researchers wanted to see how far the level of Keseneng Village participation was in managing and developing Keseneng Tourism Village. With the role of the community in the management and development of Keseneng Tourism Village, later it can have a positive impact on the people of Keseneng Village.

\section{METHOD}

The type of research approach used in this study is qualitative research. Design in research is case study research. Case study research (field research) is research that aims to find out or study intensively a natural / social phenomenon to find the linkages between various accompanying phenomena. The data sources used in this study are primary data and secondary data. Primary data in this study were obtained by researchers directly in the field from the key informants (keyperson) concerned in accordance with the subject matter discussed. The sampling technique in this study was conducted by purposive sampling . Data collection techniques were obtained by interview, documentation, direct observation of the Keseneng Village community.

This research using triangulation techniques. Triangulation technique means that researchers use different data collection techniques to get data from the same source. The triangulation technique used is as follows: (1) Comparing observational data with interview data. The actions taken by the researchers at this stage were to compare the two observations in the field, namely regarding community participation in the development of the Silent Tourism Village with the results of interviews from Keyperson. (2) Compare what people say in public with what is said personally. (3) Compare the results of interviews with the contents of a related document.

The level of community participation in the development of Tourism Village is measured by using the participation ladder of Arnstein (1969) known as the eight steps of community participation (Eight on the ladder of citizen participation).

In Arnstein concept explained that community participation is based on community strength to determine a plan or a program. Each ladder is differentiated based on the level of community strength in determining a plan / program. In general, in this model there are three levels of categories, namely: (1) Non-participation, (2) Degree of Tokenism, (3) Degree of Citizen Power.

The first and second levels of Manilupation and Therapy are categorized in Non participation. Manipulation ladder only aims to educate, educate and treat the community. Whereas in the second ladder, therapy has communication but is still limited, the initiative comes from the government (power holders) and only one direction.

Informing Ladder, Consultation and Placation are categorized in the Degree of Tokenism, namely community participation has been heard and argued but they do not have the ability to get assurance that their views will be considered by the holders of power, at this stage community participation 
has very little possibility of producing changes in society.

Partnership Ladder, Delegated Power and Citizen Control is categorized in the Degree of Citizen Power where the community has an influence on the decision making process of community participation. The community has entered the space for determining the process, results and impacts of the policy policy.

\section{RESULTS AND DISCUSSION}

Tourism is a tourist activity for tourists to travel from one place to another for various activities. Tourism has the potential to improve people's welfare because of the multiplier effect, so that tourism development needs to be carried out.

Community-based tourism is an empowerment approach that involves and puts the community as the subject or main actor in sustainable tourism development (sustainable development paradigm). Sustainable development as development that maintains the sustainability of the social life of the community, maintains an increase in the economic welfare of the community, and maintains the quality of the environment of the community. The need through tourism can increase economic growth, which in turn can have a long-term impact on the social life of the community such as improving the quality of education, improving the quality of life of the community, and improving the quality of tourism and the surrounding environment.

Keseneng Tourism Village is one of the Tourism Villages in Semarang Regency. Keseneng Tourism Village was used as a Tourism Village in May 2010 at the initiative of the Semarang Regency Tourism Office at that time because of the potential in Keseneng Village. The community is involved in the development of the Keseneng Tourism Village so that the development of Desa Wisaya can provide benefits that can be enjoyed by the local community.

The results of the study show that the community participates in the development of tourist villages, there is a tourism potential that can be used for the survival of the Keseneng Village community. Based on the results of observations and interviews of Keseneng Village informants, community participation given in the development of the Keseneng Tourism Village was as a form of planning, implemen-tation and supervision.

The participation of the Keseneng Village community began at the beginning of a tourist attraction in Keseneng Village. Pokdarwis $\mathrm{C}_{7} \mathrm{~B}$ is one of the results of community participation in the management of tourism in Keseneng Village. However, along with the development of the Keseneng Tourism Village until now, the establishment of Pokdarwis has been established, the management of tourism villages is only carried out by Pokdarwis $\mathrm{C}_{7} \mathrm{~B}$, while the community helps in managing outside tourism objects. In his opinion (Rasoolimanesh \& Jaafar, 2015) said that all levels of society are required to participate in tourism planning and decision making in order to feel the impact of economic development.

Based on the results of study in Keseneng Village, the level of community participation carried out in the development of Tourism Villages using the level of Arnstein participation can be grouped as follows in the appendix 
The level of community participation in the development activities of the Keseneng Tourism Village in the form of planning, implementation and supervision as a whole is at the stage of Placatation. This means that in the process of implementing community participation activities, they have been able to communicate with the government well and there have been negotiations or deliberations from representatives of the community. The community provides input in the form of ideas and ideas more significantly in determining the results of decisions, but their ideas and ideas are still calculated by the government.

The involvement of the Keseneng Village community that has been carried out since the beginning has become one of the factors that makes community participation to date. Community participation carried out from the beginning of the formation can increase the likelihood of participation going well in the future. This is because with the involvement of the community from the beginning, the level of self-responsibility towards the program can increase. Pokdariws which is one of the institutions that manage tourism activities in Keseneng Village is one of the places for the Keseneng Tourism Village community participation. According to (Hakim \& Fafurida, 2018) said that if the management of tourist attractions managed by the local community will increase community participation.

The development of tourist villages is considered by the community to be very appropriate, because the concept of tourism villages is considered to be able to accommodate community involvement in the development of tourism in Keseneng Village. So that it can increase the local wisdom of the community to become an attraction for tourists who visit.

Development of tourist villages there must be obstacles and obstacles that are the cause. From the results of study conducted by researchers with Pokdarwis Management, Traders and Government have several obstacles that hinder community participation in the development of tourism villages. The Inhibiting Factors of Community Participation in Tourism Village Development include:

First, lack of funding. In each activity, besides the subject being the main factor, other supporting factors are the lack of funding. However, if the supporting factors do not exist, it will become a constraining factor because in each funding activity is the most important thing so that activities can run.

Second, the quality of Human Resources (HR). It is well known that some people still consider this factor that can influence the desire and ability of the community to participate in the development of tourism villages. The lack of skills and skills of the community is very inhibiting the development.

Third, knowledge and insight of the community regarding tourism villages. Lack of knowledge and insight into community tourism can also lead to reduced public awareness of the development of tourism villages. The community, especially in tourist areas, is required to understand and be aware of the existence of tourist villages and to have knowledge and insight into tourism, especially tourist villages.

Fourth, the facilities and infrastructure are not yet complete. Facilities and infrastructure are one of the important factors in tourism. Keseneng Tourism Village in its 
development, does not yet have adequate facilities and infrastructure. With the existence of tourism support facilities and infrastructure, it is expected to increase tourists and increase the income of Keseneng Tourism Village.

The activity of developing tourism villages is not always going well. Sometimes community participation in the participation of activities still has obstacles. Not infrequently these obstacles make the tourist village run backwards and lose to the new tourist village. For this reason, the need for evaluation from the government, the community and Pokdarwis as the manager of the Keseneng Tourism Village.

Based on the results of the study, the efforts that have been made village government and Semarang district Government to increase the participation of Tourism Village Keseneng namely: (1) Dissemination information about tourism, especially tourism villages to the community and fostering tourism villages. (2) Provide training related to tourism villages. (3) Participate in marketing and publicizing Keseneng Tourism Village.

While the efforts made by the Keseneng Village community, especially the Pokdarwis management as the manager of the Keseneng Tourism Village are: (1) Inviting speakers from Yogyakarta for training on village tourism management and training in making wicker. (2) Holding a culinary culinary culinary training program as an icon of Keseneng Tourism Village. (3) Hold comparative studies in more advanced tourist villages as learning material. (4) Dissemination to the Keseneng Village community regarding tourism villages.

\section{CONCLUSION}

Based on the results of the research and discussion on the level of community participation in the development of Keseneng Tourism Village, conclusions can be drawn as follows:

(1) The level of Keseneng Village participation in the development of the Keseneng Tourism Village using the Arnstein ladder is in the stage of Placatation. This shows that communication carried out by the community and the relevant government has been done well. The community also has the opportunity to place its representatives in a Keseneng Tourism Village development activity.

(2) Factors in the Keseneng Village community barrier in the development of Keseneng Tourism Village are lack of funding, the quality of Human Resources, knowledge and insights of the community regarding tourism villages, and incomplete facilities and infrastructure.

(3) Efforts are made to overcome these obstacles by conducting tourism information dissemination, providing skills training, fostering tourism villages, participating in marketing and publishing Keseneng Tourism Village, as well as comparative studies to other tourist villages.

\section{REFERENCES}

Arnstein, S. R. (1969). A Ladder Of Citizen Participation. Journal of the American Planning Association (JAPA), 216-224.

Dinas Pariwisata. (2017). Buku Profil Pariwisata Kabupaten Semarang. Semarang: Dinas Pariwisata Kab.

Semarang. 
DISPAR. (2013-2017). Statistik Pariwisata Kabupaten Semarang. Semarang: Dinas Pariwisata Kabupaten Semarang.

DISPORAPAR. (2012-2017). Statistik Pariwisata Provinsi Jawa Tengah. Semarang: Dinas Pemuda, Olahraga dan Pariwisata Provinsi Jawa Tengah.

Gubernur Jawa Tengah. (2012). Peraturan Daerah Nomor 10 Tahun 2012 Tentang Rencana Induk Pembangunan Kepariwisataan Provinsi Jawa Tengah Tahun 2012-2027. Semarang: Pemerintah Provinsi Jawa Tengah.

Hakim, M. A., \& Fafurida. (2018). Studi Pariwisata Kabupaten Magelang, Kota Surakarta dan Kota Semarang Beserta Strategi Pengembangannya. Indonesia Journal of Development Economics (EFFICIENT) Vol. 1 No. 2, 160-169.

KEMENKUMHAM RI. (2011). Peraturan Pemerintah RI Nomor 50 Tahun 2011 Tentang Rencana Induk Pengembangan Kepariwisataan Nasional. Jakarta: Kementerian Sekretaris Negara Republik Indonesia.

Mak, B. K., Cheung, L. T., \& Hui, D. L. (2017). Community Participation in the Decision-Making Process for Sustainable Tourism Development in Rural Areas of Hongkong, China. MDPI Sustainability Journal 9, 1695, 1-13.
Nurseptiani, D., \& Mustam, M. (2015). Strategi Pengembangan Pariwisata di Kabupaten Semarang. Semarang: FISIP Universitas Diponegoro.

Pemerintah Kabupaten Semarang. (2015). RPJMD Kab. Semarang tahun 2016-2021. Semarang: BAPPEDA Kabupaten Semarang.

Pemerintah Kabupaten Semarang. (2015). Surat Keputusan (SK) Bupati Kabupaten Semarang Nomor 556/0424/2015. Semarang: Bupati Kabupaten Semarang.

Rahayu, F. (2006). Analisis pengaruh sektor pariwisata terhadap perekonomian Kota Bogor. Journal IPB.

Rasoolimanesh, S. M., \& Jaafar, M. (2015). Community Participation toward Tourism Development and Conservation Program in Rural World Heritage Sites (WHS). Tourism - From Empirical Research Towards Practical Application Chapter 1, 1-14. DOI: $10.5772 / 62293$.

Taufiqurrohman, M. (2014). Strategi Pengembangan Pariwisata Serta Kontribusinya Pada Penerimaan Retribusi Kota Pekalongan. Economics Development Analysis Journal (EDAJ) Vol. 3 No. 1, 81-91.

Wahidin, N. (2017). Strategi Pengembangan Desa Wisata Gemawang Di Kabupaten Semarang. Semarang: Universitas Diponegoro. 


\section{APPENDIX}

Table 4 . Results of Analysis of the Level of Community Participation in Skills in Development Keseneng Tourism Village

\begin{tabular}{ll}
\hline & \\
No. Characteristics of Arnstein $\quad$ Research Results in the Field & $\begin{array}{l}\text { Conclusion Comparison } \\
\text { of Characteristics of } \\
\text { Arnstein with Research } \\
\text { Results }\end{array}$ \\
\hline
\end{tabular}

1. Manipulation

The community involvement Government participation There is a match function only aims to educate for the community to between the results of and educate the community. educate the public to be the research of Keseneng aware of tourism by Village community There are relatively few conducting discussions at participation and the dialogues and discussions. the initial stage of formation. characteristics of the manipulation level of the Arnstein ladder.

\section{Therapy}

The community is involved in The community participates There is a match participation because of the because they think they between the results of compulsion for change. improve their lives. the research on Communication already exists Communication carried out Keseneng Tourism but is still limited, initiatives is only one-way from the Village community coming from the government government. The participation and the (holders of power) are only community follows the therapeutic one-way. $\quad$ government. characteristics of the Arnstein ladder. 
The provision of information The existence of information There is a conformity in and communication has been and communication the characteristics of carried out a lot but it is still provided by the community. information giving and one-way. They only followed reciprocity by the Community opportunities to directions from the Keseneng Village reciprocate the results of government for the community in the effort information and development of Keseneng to develop Keseneng communication are still Tourism Village. Tourism Village. limited. Limited community opportunity to develop Keseneng Tourism Village.

4. Consultation

Communication conducted by The existence of two-way There is conformity in the community is two-way consultation activities in the the characteristics that with the absorption of development of Keseneng occur during the aspirations. Tourism Village from the consultation phase There has been a proposal government and the between the government submitted by the community community in absorbing and the Keseneng Village and hope that aspirations have community aspirations. community in the been heard, but there is no The community has absorption of aspirations guarantee of being heard / submitted a proposal to fund and two-way considered. the development of the communication. Keseneng Tourism Village to There is a suitability for build facilities and the submission of infrastructure. funding proposals from the community. 
Communication has gone well Communication has been There is conformity in between the community and carried out by the Keseneng the characteristics that

the government.

Communities have the opportunity to place their representatives in an activity or project.
Village community with the

government.

The community involved to participate in the development of Keseneng Tourism Village. occur at the stage of disability, namely the placement of representatives in an activity and communication that has been carried out.
6. Partnership

The community is able to establish partnerships with outside parties. There is an equal position of society and government.
Keseneng villagers have not been able to establish cooperation in terms of partnerships with outside parties.

7. Delegation of Power (Delegated Power)

The community has more power than the government in making decisions.
Keseneng

Community does not have higher rights than the government as the decision maker
The absence of conformity in the characteristics of the Arnstein ladder partnership with the characteristics of the partnership results of the study.

Village The absence of conformity in the characteristics of delegated power because the highest authority is the government.

\section{Citizen Control}

The community has full The community does not control over the decisions and sustainability of an activity. have full power over decisions and sustainability in the development of The function of government involvement is minimal. tourism villages. Community participation The lack of conformity of Citizen Control characteristics of Arnsten's level with the characteristics of the research results in Community participation is so high that the community is the highest holder of power. has not been maximized so that the people of Keseneng Village are not yet as holders of power. 